have been minimized. First, the Supreme Court of the United States will not discharge prisoners held under a state sentence when the state demurs at the hearing on a properly granted writ of habeas corpus. Second, the Supreme Court held that the federal statutes on habeas corpus must be observed by the district court.

This second conclusion follows from the order in Moore v. Dempsey which directed that a hearing be held to determine the facts. ${ }^{22}$ The federal statute states, assuming of course that the petition on its face justified the issuance of the writ, that at the second stage in habeas corpus proceedings the "judge shall proceed in a summary way to determine the facts of the case, by hearing the testimony."73 This was the type of hearing ordered by the Supreme Court of the United States in Moore v. Dempsey. ${ }^{74}$

\title{
TITLE I OF THE NATIONAL RECOVERY ACT ${ }^{x}$
}

MaICOLAr P. SHARP*

W

ORKERS and persons dealing with corporations, as well as stockholders, are of course affected by the policies of corporations' rulers. The relationship may be developing a new theory of the position of these rulers, modifying the traditional view that it is the stockholders' interests alone that concern ordinary corporation managers. In the separate affairs of a single corporation, indeed, it may be that stockholders' interests must

$7^{2}$ To the effect that where the application for the writ is directed to the Supreme Court of the United States, it was the common practice of that court to dispense with the hearing, see, I2 R.C.L. I234; 3 Fed. Stat. Ann. r64.

${ }_{73}$ Rev. Stat. $\S 76 \mathrm{r}, 28$ U.S.C.A. $\$ 46 \mathrm{x}$ (I928). Mr. Justice Pitney in the majority opinion of Frank v. Mangum said: "The effect (of the federal statutes on habeas corpus) is to substitute for the bare legal review that seems to have been the limit of judicial authority under the common-law practice, and under the act of (I679) 3 I Car. II c. 2, a more searching investigation, in which the applicant is put upon his oath to set forth the truth of the matter respecting causes of his detention, and the court, upon determining the actual facts, is to "dispose of the party as law and justice requires." 237 U.S. 309, 33r, 35 Sup. Ct. 582, 588-589 (I9r5).

7426 I U.S. $86,92,43$ Sup. Ct. 265,267 (r923).

Where objection is taken to the writ of habeas corpus on the ground that it was irregularly or improperly issued . . . . the writ may be quashed upon application made to a divisional court on motion for an order nisi; and the objection should not be raised on motion to discharge the prisoner upon the return to the writ. Io Halsbury, op. cit., silpra, note $24, \$$ I37. Silpra, note 32.

x The writer's personal observations, first as a member of the law faculty of the University of Wisconsin during the last six years; and second, as a member of the legal division of the National Recovery Administration in the summer of 1933 , are the basis of this comment. The text of this comment was completed October I8, I933. Title II of the Act, not considered here, deals with public works.

* Visiting Associate Professor of Law, the University of Chicago Law School. 
continue to control, and that there will be only more careful definitions of their rights and the rights of their corporations, in relation to managers. On the other hand, it may be that the views of some of the more imaginative industrial rulers will prevail; and that even the separate organizations of single corporations will reflect more and more, not only democratic traditions, but elements from American and European theories of the aristocrat's position. ${ }^{2}$ With opportunities for cooperation among business units, moreover, workers and industrial leaders may be developing, out of familiar materials, a new concept of industrial government.

The papers contained in America Faces the Future, ${ }^{3}$ published early in I932, are significant contributions to the concept. Here are collected, among other things, reports of agencies of the American Federation of Labor and the United States Chamber of Commerce, in favor of attempts to plan industrial development; and the statements of such different leaders as Mr. Swope and Governor La Follette, agreeing on the importance of attempts to stabilize industrial operations and employment, and improve industrial government.

The positions of Governor La Follette and Senator La Follette may be particularly worth recalling at this time, partly because their contributions to the growth of the idea expressed in the Recovery Act have been less noticed recently than other contributions, and partly because thoughtful and instructive scepticism about such legislation is a natural element in the tradition to which they belong. Their contribution is of course only one among the many, which, coming from various countries and various periods of history, and from a multitude of business and government leaders, created the Act. But any limited discussion of the history, terms, and administration of the Act must be rather arbitrarily selective.

Before a special session of the Wisconsin Legislature, convened November 24, x93 I, Governor La Follette made an address, among other things outlining and advocating a bill "to promote the stabilization of industry." 4 The bill provided for the equalization of working hours. It further provided exemption from the state anti-trust laws for business groups associ-

2 On these questions about the corporation and government see Dodd, For Whom Are Corporate Managers Trustees?, 45 Harv. L. Rev. II 45 (I932); Berle, For Whom Corporate Managers Are Trustees: A Note, 45 Harv. L. Rev. 1365 (1932); Berle and Means, The Modern Corporation and Private Property (1932), especially Book IV, Chapter IV. The writer's views were briefly expressed in a book review in $22 \mathrm{Am}$. Econ. Rev. 120 (1932).

3 America Faces the Future, edited by Charles A. Beard (rst ed. 1932).

4 The bill was introduced in the Assembly by Professor Harold Groves, of the Economics Department of the University of Wisconsin, Assemblyman from Madison; and in the Senate by Senator Thomas Duncan of Milwaukee. The address of Governor La Follette is printed in part in America Faces the Future, at 35I. 
ated for stabilization and self-government. Each group was to be required to submit its cooperative activities to "a public policy committee consisting of not less than three members who are selected to represent the interests of the consumers, employees, and other groups distinct from, but affected by," the activities of the group in question. Each group was to be required moreover, as a condition of its privileges, to secure and keep the approval of the Department of Agriculture and Markets and the Executive Council of the State. There had been discussion of a provision compelling minority members of an industry within the state to come into voluntary associations organized under such a law, and controlling defined state markets; but no such provision was embodied in the bill. Among other things, it was recognized that the effective operation of the groups in question would be limited by the geographical position of this single state. The administration bill passed the Progressive Assembly, but was defeated by one vote in the conservative Senate.

The bill followed a course of administrative activity begun the previous summer. Two groups of manufacturers, influenced doubtless by growing general interest in the idea, had discussed the development of trade association activities in conferences called by the Governor to consider the possibility of various types of cooperation between industry and the state. One group, which had some prospect of controlling its markets, gave consideration to a memorandum drawn up as a result of conferences between representatives of the industry and economic and legal advisers to the Governor. The memorandum contained this brief outline of the type of organization contemplated:

Stability is to be secured by the industry's control of production. For the protection of the public, as much internal competition as possible, with respect to quality, service and specific prices, should be preserved. Production, for example, might be allotted in proportion to figures derived not only from past production, but from orders secured or available for particular units. Moreover, to serve as a check on the power of the organized industry, it would seem necessary that decisions of the industry's representatives about production, prices, and employment'should be subject to examination by a body representing interests outside the industry and affected by its policies. The industry's trustees, formulating its production policies, should be able to satisfy an advisory group chosen to represent labor and consumers that the industry is not following unreasonable policies. If the trustees fail to satisfy such a group, the agreements of the units in the industry should cease to be binding and the industry should lose the advantages of cooperation with the public. The industry's trustees might well be brought into touch with investors and investment bankers contemplating new investments in the industry through such a group. The advisory group should work in cooperation with appropriate public agencies and should be appointed by a representative of the public. It seems unnecessary to attempt to describe an organization in further detail; an organization following these outlines could undoubtedly be set up in conferences between representatives of the industry and representatives of the public. 
For a variety of reasons, the suggested organization was never effected. The lumber manufacturers of the state, the second of the groups, did, however, form a somewhat similar organization during the summer and early fall, which was in effect for a year. ${ }^{5}$ It was recognized from the start that competitive conditions in the lumber industry would limit the effectiveness of such an organization, whether for harm or good. At the same time it was thought that the creation of such an organization might be suggestive. The preservation of competition, internal or external or both, and the creation of a check on any possible monopoly power, were relied on to justify such organizations under the state and federal anti-trust laws, even without amendment.

The preservation of competition and the creation of adequate checks on the power of manufacturers' associations were essential to any sound development of such a scheme, in the judgment of Governor La Follette. Similarly, Senator La Follette indicated concern about the preservation of competition and the protection of the public, in the questions which he asked industrial leaders who appeared before the subcommittee of the Committee on Manufacturers of the United States Senate in the early winter of the same year. ${ }^{6}$ How were the efficient, low cost units of an industry to be given their legitimate opportunity to increase their fractions of the total production under a system of manufacturers' association stabilization? What sort of limits on price increases were necessary, desirable, or possible in such a scheme? The significance of these questions is emphasized by current developments.

A good deal of opinion favorable to attempts at planning and stabilization developed quietly in the year or so before President Roosevelt's inauguration. ${ }^{7}$ In his Commonwealth Club San Francisco speech, a philosophy of industrial government was outlined by Mr. Roosevelt. ${ }^{8}$ A combination of various elements effected the drafting and passage of the Recovery Act.

Title I of the Act authorizes voluntary and legally non-enforceable "agreements" and enforceable "codes" binding industrial units and

5 See a note on the agreement in the American Lumberman of September 3, I932, 38.

${ }^{6}$ Hearings before a subcommittee of the Committee on Manufactures United States Senate, Seventy-Second Congress, on S. 62r5 (7rst Congress), A Bill to Establish a National Economic Council (Government Printing Office, I932), r68, 309-3II, for example.

7 See for example, 32 Literary Digest $r_{3}$ (April 9, 1932), 89 Collier's 54 (April 30, 1932), 99 The Wall Street Jour. I (April 6, I932), for comments on New State Ice Co. v. Liebmann, 285 U.S. 262 (1932); cf. 134 Comm. and Fin. Chron. 2209-10 (March 26, 1932).

8 New York Times, September 24, 1932, p. 6. 
groups to cooperate in efforts to stabilize and revive interstate commerce. Opportunities for the organization of labor must be provided for in agreements and codes; and they must not permit "monopolies" or "monopolistic practices." Provision is made for the enforcement of codes against members of industries governed by them, by means of injunctions, criminal proceedings, and proceedings by the Federal Trade Commission. Authority to cancel a code is given the President. Some protection to parties to agreements and codes is authorized, against the effects of foreign competition.

The Act was approved June I6, and for the administration of Title I an organization was at once created by the President's order, headed by General Johnson as administrator. The preliminary discussion of codes with representatives of industry, and the subsequent conduct of hearings and preliminary recommendations of approval or disapproval, were the functions assigned to deputy administrators. These are men of business experience, and they and their staffs do between them much of the essential work of the Administration. Advisory committees representing consumers, workers, and "industry" (managers and owners) were made part of the Administration, and their representatives are assigned to protect the interests in question at various stages in the formation, consideration, and administration of agreements and codes. A number of staff divisions -public relations, administration, economic, legal-assist and advise the deputy administrators and administrator. In particular, the Division of Economic Research and Planning has grown into a large organization for the study of economic problems raised by the work of the Administration, and for the recommendation of policy to the Administration. Except as to labor, in the food production industries the administration of the Act has been delegated to the Agricultural Adjustment Administration. The promotion of the President's Reemployment Agreements required the creation of local and state administrative units, with which the public is familiar. New problems have required and will continue to require the creation of new administrative agencies, to deal with such problems as those of labor relations, prices, and enforcement.

Labor provisions of the Cotton Textile Code, approved July 9, and production and price provisions of the Iron and Steel Code, approved August I9, I933, may be somewhat arbitrarily selected as indications of the problems, and their tentative solution, of industrial self-government.9

The Cotton Textile Code, among other things, reduced the maximum

See particularly the administrators' reports recommending approval of these codes, published in part as footnotes to the codes in Prentice-Hall's Federal Trade and Industry Service, I2.00I, r2. 89r, and in full by the Government Printing Office. 
hours of labor and increased the minimum wages prevailing in the cotton textile industry. It was recognized that a resulting increase in labor costs would be likely to interfere with the operation of marginal mills in the industry, and so decrease employment. To counteract this effect, as well as to limit night work, overproduction, and price declines, it was provided that machines could be operated only eighty hours a week in the industry. Again, of course, the immediate effect intended was to send some orders to relatively "uneconomic" mills, and limit employment opportunities and production at more "economic" mills. Whether the beneficial effects of spreading employment, eliminating bad competitive labor practices, and limiting price declines, will prove to have outweighed the ill effects of limiting employment opportunities and production by increasing costs and limiting machine hours, will probably never be determined accurately, in view of the many uncontrollable variables which affect economic phenomena. Though members of the industry appear reasonably confident, it is, of course, possible that such a cooperative effort to control production interferes with price adjustments essential to recovery.

Other codes have, of course, followed the Textile Code in reducing maximum hours and increasing minimum wages, and most of them have sought to secure compensatory market advantages by production and price control. In such industries as coal, crude oil production, and lumber, where competition is extreme, it seems likely that, if it can be effected, market improvement is peculiarly desirable. In every competitive industry, indeed, there seem to be persistent divisions between the relatively efficient and the relatively inefficient, not operative in the case of monopolistic public utilities, which assure a degree of protection to the buyer.

In the case of a relatively closely organized industry like steel, nevertheless, the appearance of elaborate production and price-control code provisions called for careful consideration on the part of the Administration. In the sections of the Steel Code limiting the expansion of furnace capacity and authorizing the industry's administrative body to control production, there is no express provision for encouragement to progress in the form of favor to low cost producers. And in the sections providing for open price, basing point, rail freight, delivered prices, with authority to the industry's administration to set minimum prices, there was little express protection to buyers in the Code as submitted at the hearing. It was finally agreed that the maintenance of competitive conditions in the industry should, with other matters, be the subject of study for a ninety-day trial period, on the part of the industry's administration and a committee of the Recovery Administration. A provision to this effect was inserted in the Code before 
its approval, ${ }^{\mathbf{x}}$ together with provisions making the operation of the production and price provisions by themselves subject to the disapproval of the President. The possibility that employment and purchasing will only be discouraged by such efforts to control market demoralization is apparent in the speculation which has appeared with respect to an increased price level on some items under the Code. On the other hand, insistence on lower rail prices as a condition of government financing is a reminder that perhaps not every fall in prices prolongs a depression.

The combination of industrial groups to deal with problems of the depression, the essential feature of the program of the Recovery Act, appears a sound step, both in its immediate and permanent effects. At least the groups in question are furnished with administrative organization for collective judgment and action on any problems that may arise. On the other hand, there may have been inadequate recognition of the inherent limitations of such combinations in effecting quick improvement in employment and prices.

A considered judgment on the limitations of manufacturers' associations' activities has prevented Governor La Follette and Senator La Follette from making manufacturers' association stabilization the most important element in their programs for present industrial recovery. Instead they have insisted that the best means of dealing effectively with the depression is an extensive program of public works. They have each at the same time done perhaps as much as anyone engaged in government to advance through preliminary stages the ideas subsequently embodied in Title I of the Recovery Act.

In the course of the next thirty years, perhaps under the influence of continued and renewed depression, the ideas embodied in Title I of the Recovery Act may provide industry with a means of preventing overexpansion (if not of curing depressions), as well as a new concept of industrial government. In the meantime, as the country knows, the most important immediate question is whether industrial recovery is to come naturally, aided perhaps by the Recovery Administration, or whether it will require the aid of further collective action on the part of the country.

A number of legal questions about the Act may be presented within the next few months. It is indeed an indication of the extraordinary spirit of the country that business men have not generally interfered with the experiment, by retaining lawyers to oppose it. But the questions may eventually have to be decided. What is a "monopoly" or a "monopolistic" practice; and how can the question be raised? Are "liberty" and

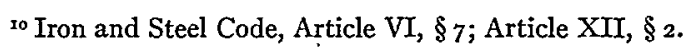


"property" unduly limited by the Act? How far does it and how far can it authorize the President to exercise power in approving codes, and providing for the decencies of administrative procedure with a view to their enforcement? Is the Act a regulation of "interstate commerce?" Does the section of the Act relating to foreign trade authorize the President to protect any industry operating under an agreement or a code against any foreign competition? ${ }^{3 x}$ Or is protection authorized only against trade disadvantages resulting only from the existence of the agreement or the code; and is the section to be read in the light of current attempts, perhaps more reasonable than they seem, to reconcile the work of the Recovery Administration with the development of international cooperation? The world wheat agreement, ${ }^{12}$ which may contain some suggestions for the copper producers, is an indication of the position the President may take, in coordinating his efforts for the promotion of domestic recovery and his efforts for the promotion of world stability.

"For a brief discussion of the sort of industrial organization provided for in the Act, and its place in the combinations policy and constitutional tradition of the United States, see Sharp, Movement in Supreme Court Adjudication, 46 Harv. L. Rev. 36r, 397-399 (r933); id., 593, 6II, note 250. See also Wahrenbrock, Federal Anti-Trust Law and the National Industrial Recovery Act, 3 I Mich. L. Rev. Ioog (I933). Since the enactment of the Agricultural Act and the National Recovery Act, favorable judicial opinions have been expressed on the validity of such legislation. United States v. Caliston Packers, (Equity ${ }_{3}^{627-S}$, Southern Division of United States District Court, N. Dist. Cal., Oct. 2, I933) and cases cited; People v. Nebbia, 262 N.Y. 259 , 186 N.E. 694 (1933).

${ }^{12}$ Obstacles to effective control of production appear of course in a serious form in the case of wheat. At the same time the drafting committee of the world conference outlined the principles which should govern production control, including the principle that the efficient producer should be encouraged in the interests of the consumer. The agreement contemplates substitution for irrational national tariffs of rational international control. Whatever difficulties wheat control may face, the principles embodied in the agreement may be suggestive for other industries. For the drafting committee's statement, see New York Times, June 25, I933, p. x. For a recent summary of the agreement and its operation see $137 \mathrm{Comm}$. and Fin. Chron. 2878 (October 21, I933). See also Sir Arthur Salter's views on the desirability and possibility of a free and yet "coordinated economy, on a world scale." Salter, Planning the Future Economic State, New York Times Magazine, September Io, I933, p. 3. 